\title{
Public hearing procedure in the management of city development: analysis of the world experience
}

\author{
Zinaida Ivanova*, and Nina Danilina \\ Moscow State University of Civil Engineering, Yaroslavskoe shosse, 26, Moscow, 129337, Russia
}

\begin{abstract}
In recent decades, public participation in the management of urban development programs has become one of the most important aspects for the sustainable development of the society. The article focuses on public hearing method that aims to extend citizen involvement in the management of the community. The authors consider the ways of organizing and holding public hearings and public discussions examine the effective factors of the international experience, analyze legislative and regulatory documents, and study different conduct procedures and methodological materials related to the topic. The study investigates the comparative analysis of the procedures for conducting public hearings in Russia, Australia, the United States, Canada, Denmark, and India. The authors arrive to the conclusion that each country has developed specific context-based procedure strategies for citizen participation in discussing important social problems that depends on actual social development, democracy level and the forms of local self-government. The study identifies the shortcomings of the Russian legislation on public hearings and public discussions in that may lead to the lack of citizen participation in management urban affairs and therefore requires improvement using positive experience of other countries.
\end{abstract}

\section{Introduction}

Improvement of the procedure for public hearing is a necessary condition for expanding human rights in decision making for managing urban development processes, in line with democratic ideals. The State Duma of the Russian Federation adopted a new law on public hearings in town planning in December 2017. The law includes the transition from the procedure of public hearings on certain issues of town planning activity to the procedure of wide public discussions, including also Internet use. The reason for the adoption a new law is derived from the decision on a large-scale renovation in Moscow. Recent legislation changes the procedure for conducting public hearings according to the current policy. Only those affected by a decision and so interested in the results will participate in the procedure of public hearings. This point is specified in the law. At the same time, partial transfer of the public hearings into a correspondence form may exclude some groups of potential

\footnotetext{
*Corresponding author: ivanovazi@mail.ru
} 
participants from the decision-making process. If a significant part of the public hearing procedure is translated in Internet and on-line form, then people lacking computers or technical education may not be able to participate in discussions and will have fewer opportunities to collaboration. Elderly people can be classified in this vulnerable category.

Citizen participation in managing of the affairs of human life is a world practice. A variety of public participation procedures has been derived from recognition of basic human rights regarding self-government in different countries. Awareness of these tools is essential for perceiving and adaption of effective self-government experience in our country, given that the improvement of the forms and opportunities for public involvement on issues concerning the management of urban development processes is constantly going on. In European countries, most issues of city development, the implementation of urban projects are supported by the approval of citizens.

\section{Literature review}

The problems of organizing and holding public hearings have received much attention from scientists and practitioners in Russia and abroad. Formally, the researches can be divided in two groups. The first one considers the institution of public hearings itself as the object of research on such aspects as the best structure, functional performance and efficiency $[1,2,3]$. The second group of studies investigates specific cases of public hearings, describing and analyzing diverse experiences in various countries. Public participation in environmental management and more especially in problem of biosphere compatibility of cities and settlements is the most relevant for city development. For example, architectural and city-planning projects, which can adversely affect the ecological environment of the city, must be necessarily studied and supported by citizen participation, and achieve their approval. In Denmark, all environmental projects pass the procedure of public hearings or are discussed at conciliation conferences [4]. Architectural and town-planning projects with environmental content are subjected to debates in the United States, Canada, Western Europe countries. For example, the public participation practice required under established environmental impact assessment (EIA) systems is considered in the study conducted by Heather L. Almer и Tomas M. Koontz from the School of Natural Resources at The Ohio State University.

Also, such projects are being discussed more and more often in Eastern Europe. The authors pose problems and explore the conflicts that often arise during public hearings in Bulgaria, noting their shortcomings. Nevertheless, Bulgarian public hearings do provide widespread benefits that favor democratic governance potential and empower active civil society. Public hearings often raise conflict and clash of interests of different social groups. Each side defends its interests. Developers are trying to impose their options on the public, and the city authorities sometimes try to manipulate the public consciousness. This problem is often subjected to the analyses in the works of the lawyers and sociologists [6,7].

The study of D.A. Yastrebov and O.T. Larin consider the issues of urban development regulation and manipulating public opinion in conditions of «urban conflict» in the city of Moscow [8]. Issues on energy efficiency and climate change, the use of Smart city technologies are also becoming relevant today.

The article by Johanna Schweizer and Jana Bovet analyzes the role of public participation in effective infrastructure planning on the issue of energy policy [9]. Public participation is certainly not a panacea for solving the problem, but it offers significant potential for facilitating the country's energy transformation. The main attention is paid in the article not only to the expansion of the German energy system, but also to the policy of participation at the European level. 
Of interest is the article by Jin Zhong and Arthur P.J.Mol on public hearings on the issue of water tariffs in China [10]. This article analyzes the emergence, development and ongoing functioning of public hearings in the field of setting water tariffs and assesses to what extent public hearings constitute part of a turning point in China's environmental development.

Thus, a consideration of the scientific literature reveals the existing of a variety of experiences that Russia can borrow, taking into account national, urban and climatic specifics.

\section{Materials and methods}

The purpose of this work is to acknowledge the experience of conducting public hearings by investigating the public hearings conducting procedure in different countries. The research method selected by the authors is the analyses of the documents related to such experiences. In the process of work, the authors studied laws and resolutions on holding public hearings, methodological materials, communication processes and ways of procedure holding. In particular, the analyzed documents included the Federal Law No. 455-FZ of December 29, 2017 «On Amendments to the Urban Development Code of the Russian Federation and Certain Legislative Acts of the Russian Federation» [11], the Regulation on Public Hearings in municipal education, the procedure for holding public hearings in Australia, Canada, the United States, India; the procedure for holding public hearings in New York; methodological documents related to conducting public hearings in Denmark. Also, the authors have studied the official web site of Richmond dedicated to public hearing schedules [12]. Document analysis and content analysis are the most appropriate methods for obtaining data at this stage of research, as it allows to get acknowledged with ways and procedures for holding public hearings, characterize the citizen activity in different countries, make comparative analyses of the cases and correspond the research results with the same experience in Russia.

\section{Results}

The research found a variety of social tools for conducting public hearings, developed by governments of different countries aiming at penetration of public participation into life to support the sustainability of industrial and economic growth of the cities. A number of similar methods for conducting procedure allows to unite them under the general title Citizen Conferences. Such are: Citizen Jury (American variant), Consensus Conferences (European version), Civil hearings (Civic Hearings - Russian title proposed by ECOM Center for Expertise of St. Petersburg Society of Naturalists) and the actual Citizen Conferences.

In Russia, the Federal Law no. 212-FZ of July 21, 2014 establishes the right of citizens to participate in decision making and public control over the activities of state bodies, local self-government, state and municipal bodies. Using public hearings as the possibility of public participation in city planning is provided by the Town Planning Code of the Russian Federation.

Federal Law No. 455-FZ of December 29, 2017 «On Amendments to the Urban Development Code of the Russian Federation and Certain Legislative Acts of the Russian Federation» makes several adjustments to the procedure of holding public hearings. First, the law specifies two possible models of hearing conduct: public hearings and public discussions. Second, Internet use is pointed in the law as a technique for participation in the process. Third, only those objectively concerned on the issues discussed should be 
involved in the debates. Article 5 of Federal Law No. 455-FZ specifies that public discussions and public hearings are conducted on draft master plans, draft rules for land use and development, land use planning, land surveying projects, draft regulations on land improvement, draft decisions on granting permission for conditionally permitted use of a land plot or an object of capital construction, draft decisions on granting permission for deviation from limiting parameters of the permitted construction, reconstruction of major construction sites.

The procedure for conducting public hearings is also specified in detail in the law. Internet public discussion and public hearings procedures are designed separately and explained in different terms. Notification about the beginning of public discussions or public hearings should be carried out not later than seven days before the day of posting the project on the official website or in the information systems. The duration period for conducting public discussions or public hearings on drafts of the rules for land improvement is established from the date of publication of the notification about the beginning of public discussions or public hearings and lasts until the day of final publication reporting the results of public discussions or public hearings. The period cannot be less than one month and more than three months. The conclusion on the results of public discussions or public hearings shall be published in the way established for the official publication of municipal legal acts and posted on the official website and/or in information systems. However, the law does not specify the order (obligatory or nonobligatory) of consideration the comments made on the project under discussion. The absence in the law of the item on the mandatory registration of opinions expressed by public control bodies and public itself can leave citizens without influence. In fact, the law does not provide for consideration of citizen voices in final decision. Designed procedures and measures necessary to regulate these issues are ignored. The opinion expressed by urban community has no legal status.

It should be observed that timing spent for notification, placement of the project on websites or in special audiences of municipal bodies, announcement of the beginning of public hearings varies in different countries. In Canada for example, the population receives a provisional timetable about the dates, places and issue of the hearings 30 days before the beginning of public hearings [13]. Public hearings model has three steps: general sessions, community sessions and thematic sessions.

1) General Sessions: initiator and interested groups receive general information about the project. The expert workgroup provides for impact analysis of the project;

2) Community sessions: individuals and stakeholder groups residing in areas (communities) that are likely to be affected by a police decision are informed about final outcomes of the project for their community;

3) Thematic sessions: initiator and public affected by a police decision receive detailed general and technical information about the project, including direct expert information on the issues of the session.

Meetings are open to the general public: everybody can participate except the cases of confidential meeting. The results of all public hearing sessions are published; also on the site of the environmental assessment register [14]. All documents related to public hearings, including documents referenced by the speaker (transcripts, schedules, obligations) enter the state register in due time.

In Denmark, the environmental impact assessment of the project (EIA) is the main objective for participation in public hearings [15]. All projects (even small ones) are evaluated on criteria of the type and level of environmental impact, geographical distribution, transboundary effect, duration and frequency, reversibility of impact. Public consultations are held twice, when authorities request and accept the citizen comments. These comments contribute to the decision-making process. The goal is to use the citizen 
opinion and knowledge to accurately define the objectives of the environmental assessment and finalize the project in such a way as to minimize adverse effects.

The first public consultations are held at the initial stage of the project, the latter at the stage where a preliminary assessment report can be submitted.

The decision on the final approval of the EIA document is published in the local newspaper.

The time spent for public consultations (at each stage) usually constitutes 8 weeks, including:

- Notification about place and time of public hearings

- Information about where to find relevant documents (Internet, libraries)

- Public hearings

- Minutes of the hearing

- Submission of comments to the authority

- Government officials prepare a small report, which contains their opinion and recommendations (requirements) to the customer

The report is sent to a representative authority, which decides the way for public opinion consideration. At the initial stage of public consultations, the customer prepares a brochure presenting the project and environmental issues, a plan for conducting public consultations. The brochure is posted in Internet and libraries before the public hearing. During the survey (screening) the most important environmental problems of the project are formulated, which facilitates the preparation of the brochure. Comments of the citizens taking place at the initial stage are used to define the goals and extend of ecological valuation as well as to choose the alternative variants that should be included to the EIA report.

At the second stage of public hearing, a report is discussed, and such discussion is also posed at public hearing websites and libraries. At this stage the organizers check whether all rational proposals are included in the project and whether it is necessary to collect more opinions before final approval.

The decision to approve the EIA report is announced in the local newspaper, and all the documents are posted on the website. Thus, interested persons can see the final version of the project and express disagreement when necessary.

A new method of civil society participation in governance - Format 21st Century Town Meeting - is used in the United States [16]. Such citizen's assemblies have no legislative power. Nevertheless, this is an effective way of self-organization and attracting citizens to management [17]. The program 21st Century Town Meeting was developed in order to realize in full the potential of open city meetings: to allow each participant to make a significant contribution to the process of discussion and decision-making. To this end, the participants sit at round tables for 10-12 people. These meetings imply equality and encouragement of initiative. As a rule, participants are ordinary citizens without any particular experience on the issue under discussion. They do not represent the interested parties or professional lobbyists. Each discussion group is connected by informationcommunicative technologies (ICT) to involve thousands of people in wide dialogue. Largescale meetings (between 500 and 5,000 participants) provide for importance and credibility of the results in such extend as to be taken into account by decision makers, the media, key stakeholders and general public. Founder and president of AmericaSpeaks Carolyn Lukensmeyer notes that the aim of the method is to overcome deep-rooted distrust between citizens and the government. The constant participation of citizens in the policy-making process, the provision of opportunities for action, promotes civic leadership and contributes to the realization of state priorities [18]. 


\section{Conclusions}

Analysis of different approaches to designing public hearings, rules of their preparation, organization and practices in Canada, Denmark and the United States allows to suggest that the Law on Public Hearing, adopted in December 2017 in Russia, still does not provide necessary regulation for many procedural and legal issues:

1. The law presupposes public discussions and public hearings. In both procedures of the new law, people that submit comments and suggestions will be protected by the law on personal data, so the personal data of the citizens and the protocol of public hearings will be a secret. In the US, Denmark and Canada, the discussions are open, all materials are published and participants are known. For example, all discussions are recorded in the United States. A person appointed on purpose records them in writing on a laptop computer. The content of table conversations is collected in real time and processed by the central «thematic group», which tries to determine the main points of view, positions and topics arising in during the discussions.

2. Public hearings are recommendatory in nature under the new Russian law. The law specifies that public hearings should be taken into account when making town-planning decisions, but this does not mean the mandatory implementation. While in Denmark, the decision on the final approval of the EIA document is published in local newspaper and public can appeal against this decision.

3. Conducting public discussions in Internet create possibility to submit false offers. Employees of municipalities can do these using citizen addresses at their disposal. While the proposals submitted in writing can be saved in copy and used to ask whether they were taken into account.

Acquaintance with various documents and practices of holding public hearings in different countries allow us to make the above mentioned and other comments based on comparative analysis of international and Russian experience and, consequently, leads us to conclusion that the Law on Public Hearings recently adopted in our country has serious shortcomings, which we expect to analyze in further researches.

The reported study was funded by RFBR according to the research project No. 18-011-01004.

\section{References}

1. O.B. Ivanova, S.N. Denisenko, Public hearings of the draft local budget as a form of public participation in establishing of local self-government. Financial Research 1 (54), 96-104 (2017)

2. E.V. Agapova, E.A. Baranova, Mariysky legal bulletin 15, 121-123 (2015)

3. C. Lukensmeyer, S. Haas Lyons, 21st Century Town Meetings. https://www.civicus.org/documents/toolkits/PGX_B_21st\%20CenturymeetingFinalWeb .pdf

4. Profile of the Danish system Environmental effect estimation and public participation. http://ecom.su/technologies_materials/index.php?id=472

5. H. L. Almer, T. M. Koontz, Environmental Impact Assessment Review 24 (5), 473-493 (2004)

6. E.M. Akimkin, Sociology and society: Global challenges and regional development. Materials of the 4th All-Russian sociological congress (2012, Moscow, ROS). http://www.ssa-rss.ru/files/File/congress2012/part36.pdf

7. I. Shcherbakova, Z. Zaripova, The Authority 9, 118-120 (2012) 
8. D.A. Yastrebov, O.T. Larin, Public hearings on the regulation of urban development in the situation of «urban conflict» in the city of Moscow and manipulation of public opinion

https://zakon.ru/blog/2017/1/13/publichnye_slushaniya_po_voprosam_regulirovaniya_g radostroitelnoj_deyatelnosti_v_usloviyah_gradostro

9. J. Schweizer and J. Bovet, Environmental Impact Assessment Review 24 (5), 473-493 (2004)

10. Jin Zhong and A.P.J.Mol, Journal of Environmental Management. 88 (4), 899-913 (2008)

11. Federal Law of December 29, 2017 No. 455-FZ "On Amendments to the TownPlanning Code of the Russian Federation and Certain Legislative Acts of the Russian Federation." www.consultant.ru/document/cons_doc_LAW_286726/

12. https://www.richmond.ca/cityhall/council/meeting/WebAgendaMinutesList.aspx?Categ ory $=25 \&$ Year $=2018$

13. https://www.pc.gov.au/about/core-functions/inquiries-and-studies/what-is-a-publichearing

14.http://a100.gov.bc.ca/appsdata/epic/html/deploy/epic_project_home_371.html

15. Profile of the Danish system Environmental effect estimation and public participation. http://ecom.su/technologies_materials/index.php?id=472.

16.21st Century Town Meeting. https://participedia.net/en/methods/21st-century-townmeeting

17. AmericaSpeaks. http://www.americaspeaks.org/

18. C.J. Lukensmeyer, 21st Century Town Meeting. Participatory Methods Tool Kit - A Practitioner's Manual. Eds. Stef Steyaert and Hervé Lisoir. Jointly published by King Baudouin Foundation and the Flemish Institute for Science and Technology Assessment (2005). http://ist.vito.be/en/pdf/projects/toolkitworldcaf.pdf 